http://dx.doi.org/10.12775/szhf.2016.064

\author{
ADAM GRZELIŃSKI
}

Uniwersytet MikoŁaja Kopernika, Toruń, Polska

ADAM.GRZELINSKI@UMK.PL

\title{
Eseje Hume’a i ich polskie przekłady. Nota bibliograficzna
}

Eseje Davida Hume’a są świadectwem epoki, w której powstały - czasów, gdy filozofia i nauka przynajmniej częściowo opuściły uniwersyteckie katedry, aby zadomowić się w londyńskich kawiarniach, paryskich salonach, klubach i podczas spotkań powstałych niewiele wcześniej towarzystw naukowych ${ }^{1}$. Owo zbliżenie świata filozofii i nauki oraz świata "konwersującego" miało przynieść korzyści im obu: z jednej strony pozwalało filozofii zająć się problemami praktycznymi (co dobrze widać w przypadku największych angielskich empirystów: Johna Locke’a, George’a Berkeleya i wspomnianego Hume’a, u których zagadnienia ściśle teoriopoznawcze i metafizyczne stanowiły tylko część zainteresowań), z drugiej zaś - przyczynić się do oświecenia publicznego i poprawy ludzkiego życia w tak różnych jego sferach, jak polityka, religijność, ekonomia czy krytyka artystyczna. Przekonanie o konieczności takiego mariażu Hume wyraził, przedstawiając cele, jakim ma służyć

${ }^{1} \mathrm{Na}$ temat społecznego wymiaru filozofii Oświecenia zob. teksty zebrane w tomie Znaczenie filozofii Oświecenia. Człowiek wśród ludzi, red. B. Grabowska, A. Grzeliński, J. Żelazna, WN UMK, Toruń 2016. 
pisanie esejów - krótkich, łatwych w odbiorze, powszechnie dostępnych i poruszających najróżniejsze tematy:

Mamy nadzieję - zauważał w O pisaniu esejów - że to porozumienie między światem uczonym i konwersującym, które się szczęśliwie zaczęło, będzie się wciąż udoskonalać z korzyścią dla nich obu; ale żeby tak się stać mogło, nie znam żadnego lepszego sposobu niż pisanie esejów, takich jak te, którymi staram się zabawiać publiczność. Co za tym idzie, nie mogę się uważać za nikogo innego niż pewnego rodzaju rezydenta czy ambasadora, przychodzącego $\mathrm{z}$ domeny uczoności do świata konwersacji, i będę uważać za mój nieustający obowiązek promować zgodę między tymi dwoma państwami, które w tak dużym stopniu zależą od siebie nawzajem².

Chociaż Hume postanowił wycofać ów esej z kolejnych wydań tomów zawierających inne tego rodzaju teksty, faktycznie tylko o niektórych $\mathrm{z}$ nich można powiedzieć, że zawierają „krotochwile i facecje”, za które samego siebie w nim ganił. Już chociażby wzmianka o pobożności i galanterii, które jego zdaniem zdobywają poklask ze względu na uczuciowe oddziaływanie na czytelników, wskazuje na poważniejszy cel, jakiemu służyć miały Hume’owskie eseje, a którą był program oświecenia publicznego ${ }^{3}$. Program ten, sukcesywnie przez Hume’a realizowany, zakrojony był bardzo szeroko i obejmował walkę z „zabobonami”, w tym krytykę racjonalnej teologii, popularyzację wiedzy filozoficznej poprzez wskazywanie na jej światopoglądowe źródła (eseje Sceptyk, Stoik, Platonik czy Epikurejczyk), zagadnienia estetyczne ${ }^{4}$, ekonomiczne ${ }^{5}$ i polityczne, a także wypowiedzi na rozmaite tematy społeczne i obyczajowe (choćby takie, jak małżeństwo i rozwód, zabobon czy krasomówstwo). Tę ostatnią okoliczność warto szczególnie podkreślić, ponieważ z projektem stworzenia „systemu nauk o ludzkiej naturze” Hume przystępował już do pisania Traktatu o naturze ludzkiej - swego najwcześniejszego i jak miało się po wielu latach okazać, także najważniejszego dzieła. Pisał tam tak: „stawiając sobie za cel wyjaśnienie zasad natury ludzkiej, w rzeczy-

${ }^{2}$ D. Hume, O pisaniu esejów, „Przegląd Filozoficzny. Nowa Seria” 2011, nr 4 (80), s. 16.

${ }^{3}$ Zob. artykuł Justyny Van den Abbeel na temat oświeceniowego charakteru myśli Hume’a (s. 181-200).

${ }^{4}$ Zob. artykuł Krzysztofa Wawrzonkowskiego poświęcony Hume’owskiego koncepcji kształcenia smaku estetycznego i obyczajności (s. 161-179).

${ }^{5}$ Problematyce tej poświęcił badania m.in. Stefan Zabieglik (Eseje ekonomiczne Davida Hume’a, „Nowa Krytyka” 2007, nr 20-21, s. 455-468; por. także tekst Pawła Hanczewskiego w niniejszym tomie (s. 201-218). 
wistości projektujemy pełny system nauk, budowany na podstawie niemal całkowicie nowej, na jedynej, na której te nauki mogą oprzeć się pewnie"6. Poszczególne części tego systemu miały wzajemnie się uzupełniać: logika miała zawierać teoriopoznawcze podstawy opisu człowieka oraz ujmować go w relacji do świata przyrody, części zaś pozostałe - etyka, krytyka i polity$k a$ - miały opisywać świat człowieka, jego społeczności oraz poszczególne sfery jego praktycznej aktywności w sferze obyczajów, ocen twórczości artystycznej, a także działalności politycznej i ekonomicznej. Co prawda trudno w tej zapowiedzi nie dosłuchać się młodzieńczego entuzjazmu, jakie obudziło w Humie otwarcie się przed nim „nowej sceny myśli”, ale też trzeba przyznać, że pomimo rozmaitych zawirowań plan ten z uporem realizował. Nim ten sam entuzjazm dało się jeszcze usłyszeć w zakończeniu dużo późniejszej pracy filozoficznej, jaką była Rozprawa o uczuciach ${ }^{7}$, Hume zdążył opracować poszczególne części owego systemu w kolejnych dziełach, Badaniach dotyczących rozumu ludzkiego, Badaniach dotyczących zasad moralności, a także esejach. O ile jednak zagadnieniom politycznym poświęcił już obszerne fragmenty Traktatu, a krytyce religii dwa późne, obszerne dzieła: Dialogi o religii naturalnej oraz Traktat o historii religii, na których wydaniu szczególnie mu zależało, o tyle zasady krytyki artystycznej oraz zagadnienia ekonomiczne wyłożone zostały niemal wyłącznie w esejach. Już sam ten fakt świadczy o tym, że pomimo mało akademickiego stylu wykładu oraz pewnej skrótowości wypowiedzi, należy je traktować jako pełnoprawną, choć pozbawioną systematyczności wywodu cechującego dzieła obszerniejsze część dorobku szkockiego filozofa. I chociaż wielokrotnie w historii podążano za opinią jego dziewiętnastowiecznego wydawcy, Lewisa A. Selby-Bigge’a, i przekonywano o rapsodycznym, jeśli nie pełnym wewnętrznych sprzeczności, charakterze jego pisarstwa ${ }^{8}$, wielu współczesnych badaczy skłania się do poglądu przeciwnego: „Hume jest niezwykle systematycznym filozofem - pisał niedawno

${ }^{6}$ D. Hume, Traktat o naturze ludzkiej, przeł. C. Znamierowski, t. 1, PWN, Warszawa 1963, s. 6.

${ }^{7}$ Czytamy tam: „Nie roszczę sobie pretensji do tego, że wyczerpałem temat. Dla mego celu wystarczy jednak, jeśli udało mi się ukazać, że w powstawaniu i przepływie uczuć można zauważyć pewien stały mechanizm, który poddaje się równie precyzyjnemu badaniu, jak prawa ruchu, optyki, hydrostatyki czy jakiejkolwiek innej części filozofii naturalnej” (D. Hume, Rozprawa o uczuciach, przeł. A. Grzeliński (i in.), „Filo-Sofija” 2008, nr 1 (9), s. 267.

${ }^{8}$ Pisał on, że „stronice jego [dzieł], szczególnie Traktatu, są tak przepełnione zagadnieniami, mówi on tak wiele różnych rzeczy na tak rozmaite sposoby i w tak różnych związkach, a także z tak wielką obojętnością wobec tego, co twierdził wcześniej, że jest bardzo trudno ustalić, czy nauczał tej bądź innej doktryny" (L. A. Selby-Bigge, Editors Introduction, w: D. Hume, 
jeden z nich - co sprawia, że żadna część jego filozofii nie może być rozumiana w oderwaniu od całości'. Uwagę tę należy odnieść do całokształtu twórczości filozofa - w tym do jego esejów.

Obecnie znaczenie tej części pisarstwa Hume’a przesłoniły dzieła ściśle filozoficzne - przede wszystkim Traktat o naturze ludzkiej, a także dwa tomy Badań oraz prace na temat religii. To jednak opinia stosunkowo niedawna - bardzo długo nie przywiązywano przecież zbytniej wagi do Traktatu, na co wpływ miała spowodowana doznanym zawodem opinia samego $\mathrm{Hu}-$ me’a. Późniejsze pokolenia zdawały się podzielać jego niepochlebną opinię wyrażoną w spisanej przed śmiercią autobiografii. Pisał tam: „Nigdy debiut literacki nie był bardziej niefortunny, niż wydanie mego Traktatu o naturze ludzkiej. Wyszedł spod prasy drukarskiej na świat jako płód nieżywy i nie dostąpił nawet tego wyróżnienia, by go przyjęto ze strony fanatyków szmerem niezadowolenia"10. Znaczenie Traktatu dla filozofii Hume’a dostrzeżono dopiero w XX wieku, zaś przełomową pracą była obszerna monografia Normana Kempa Smitha The Philosophy of David Hume wydana w 1941 roku. Poza tym najczęściej za dzieła podstawowe dla rekonstrukcji filozofii Hume’a uważa się jego Badania, skądinąd nie bez słuszności; w nich to bowiem Hume miałby wyrazić dojrzałą wersję swych poglądów oraz zawrzeć szczegółowe omówienie wielu kwestii, które wyznaczyły jego miejsce w historii filozofii, takich jak krytyka związku przyczynowo-skutkowego, omówienie różnych odmian sceptycyzmu, czy wskazanie na rolę współodczuwania w kształtowaniu się moralności.

Inaczej czytano Hume’a w jego czasach. Jak pisze Eugene F. Millar, współczesny wydawca Hume'owskich esejów, ich odbiór był bardzo dobry, co poświadczają kolejne wydania; zaczęto też je tłumaczyć na języki obce francuski, niemiecki i włoski ${ }^{11}$. Uznanie, $\mathrm{z}$ jakim przyjęto eseje, ucieszyło Hume’a tym bardziej, że stanowiło spełnienie jego marzeń o karierze literackiej, a także częściowo zrekompensowało zawód, jaki sprawił mu Trak-

Enquiries Concerning Human Understanding and Concerning The Principles of Morals, Oxford 1998, s. XIII).

9 J. Bailie, Routledge Guide Book to Hume on Morality, Routledge, London-New York 2000, s. 19.

${ }^{10}$ D. Hume, Mój żywot, [w:] Dialogi o religii naturalnej. Naturalna historia religii, przeł. A. Hochweldowa, PWN, Warszawa 1962.

${ }^{11}$ E. F. Milllar, Foreword, [w:] D. Hume, Essays. Moral, Political, and Literary, Liberty Fund, Indianapolis 1987 http://www.econlib.org/library/LFBooks/Hume/hmMPL0. html\#Foreword,\%20by\%20Eugene\%20F.\%20Miller (dostęp: 6.11.2016). 
tat. Choć nigdy nie odżegnał się od treści swego pierwszego dzieła, winą za niepowodzenie obarczył styl - zbyt suchy i drobiazgowy. W późniejszych publikacjach starał się już pisać inaczej - nieco bardziej skrótowo analizował kwestie filozoficzne, ale za to dyskusje te oblekał w znacznie bardziej elegancką formę - widać to, porównując $\mathrm{z}$ nim chociażby przeróbki treści w nim zawartych, które ukazały się w dwóch tomach Badań i Rozprawie o uczuciach. W dążeniu do poszukiwania prostej, a przy tym eleganckiej formy, dzięki której można wyrazić treści filozoficzne, należy dopatrywać się źródeł powstania Hume’owskich esejów.

Najogólniej rzecz ujmując, Hume opublikował 49 esejów zebranych w trzech głównych tomach: dwóch zatytułowanych Eseje na temat moralności i polityki (Essays Moral and Political, pierwsze wydanie: tom I - 1741, tom II 1743) oraz trzecim, Rozprawach politycznych (Political discourses, pierwsze wydanie: 1751). Jednak to ogólne stwierdzenie trzeba zaraz uzupełnić: kolejne eseje Hume pisał w ciągu całego swego życia: ostatni z nich, O narodzinach rządu (Of the Origin of Government) został opublikowany już po śmierci filozofa, w 1777 roku, w kolejnym wydaniu tomu Eseje i traktaty na różne tematy (Essays and Treaties on Several Subjects). Inne dodawał Hume w kolejnych wydaniach wspomnianych zbiorów tekstów, a także w tomie Cztery rozprawy (Four Dissertations) w 1757 roku - ostatnim zbiorze tekstów filozoficznych. Później (jeśli pominąć dwa eseje wydane pośmiertnie) jedynie dołączał nowe eseje do wznowień prac wcześniejszych. Jeśli zestawimy te daty z latami wydań najważniejszych dzieł, które uczyniły go sławnym, okaże się, że eseje powstawały dokładnie w tym samym czasie co twórczość Hume’a filozofa i Hume'a - historyka. Traktat o naturze ludzkiej ukazał się w latach 1739-1740, Badania dotyczace rozumu ludzkiego w 1748 roku (pierwotnie wydano pod tytułem Eseje filozoficzne dotyczace rozumu ludzkiego (Philosophical Essays concerning Human Understanding), w 1751 roku wydane zostały Badania dotyczące zasad moralności, a trzy lata później pojawił się pierwszy tom monumentalnej historii Wielkiej Brytanii.

Zmienne były koleje losów esejów: Hume nie tylko dodawał kolejne teksty do nowych edycji zbiorowych, ale też niektóre eseje z nich usuwał - tak stało się z esejami: Of Essay-Writing, Of Moral Prejudices, Of the Midddle Station of Life, Of Impudence and Modesty, Of Love and Marriage, Of the Study of History, Of Avarice i A Character of Sir Robert Walpole. Jeszcze bardziej zagmatwany był los dwóch innych, których treść zgodnie z obawami Hume’a mogła być uznana za bardzo nieprawomyślną, Of suicide i Of the Immortality of the Soul (O samobójstwie oraz O nieśmiertelności duszy). Pierwotnie miały one być 
opublikowane w zbiorze Five Dissertations przez A. Millara, stałego wydawcę Hume’a, pojawiło się nawet kilka egzemplarzy sygnalnych. Jednak za namową przyjaciół Hume ostatecznie wycofał je z tomu, dodając w zamian esej Of the Standard of Taste (Sprawdzian smaku) i tom pod zmienioną nazwą Four Dissertations ukazał się, jak wspomniałem, w roku 1757 . Oba eseje odpowiadały zresztą zawartości tomu, chociażby z tego względu, że zawierał on także $\mathrm{Na}$ turalną historię religii. $\mathrm{Z}$ drugiej strony jeśli weźmiemy pod uwagę dwukrotne fiasko starań Hume’a o katedrę uniwersytecką (w 1745 w Edynburgu i w 1751 w Glasgow), na czym zaważyła opinia o jego bezbożności, a także ostrożność, jaką zawsze przejawiał, podejmując problematykę dotyczącą religijnych dogmatów czy racjonalnej teologii, zabieg ten jest całkiem zrozumiały. Co ciekawe, w 1770 roku ukazało się (bez wiedzy Hume’a) francuskie tłumaczenie obu esejów, dla którego podstawą musiały być pojedyncze egzemplarze owego ostatecznie niezrealizowanego wydania Five Dissertations. Fakt, że Hume obawiał się reakcji na te dwa teksty, nie oznaczał, iż nie przykładał wagi do ich treści i nie chciał, aby ujrzały światło dzienne - wystarczy wspomnieć ostatnie słowa, którymi kończą się Badania dotyczace rozumu ludzkiego, aby w pełni dostrzec, jak wielkie znaczenie miały dla Hume argumenty podważające religijne dogmaty i racjonalną teologię ${ }^{12}$. Ostatecznie po koniec życia Hume dodał do swego testamentu kodycyl, w którym wyrażał pragnienie, aby jego wydawca, William Strahan, w ciągu dwóch lat po jego śmierci opublikował Dialogi o religii naturalnej, do których może dodać, jeśli uzna to za stosowne, „dwa eseje, które zostały wcześniej wydrukowane, choć nie opublikowane"13. Ostatecznie eseje te wydano w 1777 roku jako niewielką, 41-stronicową broszurkę - anonimowo, bez podania nazwiska autora i wydawcy, ale za to za wysoką cenę ośmiu szylingów (co odnotowano dwukrotnie na okładce i karcie tytułowej).

W niniejszym numerze „Studiów z Historii Filozofii” publikujemy tłumaczenie ostatniego z nieprzełożonych do tej pory na język polski esejów Davida Hume’a - Ideę doskonałego państwa w tłumaczeniu Daniela Żuromskiego. Z wyjątkiem Historii Wielkiej Brytanii, która, choć do końca XVIII wieku

12 „Jeśli przejęci tymi zasadami przebiegniemy biblioteki - pisał tam - jakiegoż musimy dokonać spustoszenia! Biorąc do ręki jakiś tom, traktujący np. o teologii albo szkolnej metafizyce, zapytujemy: Czy zawiera jakieś rozumowanie abstrakcyjne, dotyczące wielkości lub liczby? Nie. Czy zawiera jakieś oparte na doświadczeniu rozumowanie dotyczące faktów i istnienia? Nie. A więc w ogień z nim, albowiem nie może zawierać nic prócz sofisterii i złudzeń!” (przeł. J. Łukasiewicz, K. Twardowski, PWN, Warszawa 1977, s. 200).

${ }^{13}$ The Letters of David Hume, ed. J. Y. T. Greig, vol. 2, Clarendon Press, Oxford 1932, s. 453. 
traktowana była jako podstawowa na ten temat, sama ma obecnie wartość jedynie historyczną, a także kilkoma drobiazgami, polski czytelnik ma zatem dziś możliwość zapoznania się z całokształtem dorobku pisarskiego szkockiego filozofa. Przekłady niemal wszystkich esejów ukazywały się w okresie powojennym, wyjątkiem jest jedynie Of the Populousness of Ancient $\mathrm{Na}$ tions, którego tłumaczenie polskie z języka francuskiego ( $O$ ludności czasów dawnych y teraźniejszych) opublikowano dawno, bo w 1785 roku; w nowym przekładzie ukaże się on wkrótce wraz z esejami publikowanymi na łamach „Studiów” w przygotowywanym tomie Eseje pozostałe w Wydawnictwie Naukowym UMK.

\section{Wydania esejów w czasach Hume’a}

Pierwszy ${ }^{14}$ zbiór esejów: Essays Moral and Political, Edinburgh 1741; tom ten zawiera: Of the Delicacy of Taste and Reason, Of the Liberty of Press, Of Impudence and Modesty (usunięty w kolejnych edycjach po 1760 r.), That Politics may be reduc'd to a Science, Of the first Principles of Government, Of Love and Marriage (pominięte w kolejnych edycjach po 1764 r.), Of the Study of History (pominięte w kolejnych edycjach po $1764 \mathrm{r}$.), Of the Independency of Parliament, Whether the British Government inclines more to Absolute Monarchy or to a Republic, Of Parties in General, Of the Parties of Gt. Britain, Of Superstition and Enthusiasm, Of Avarice (pominięte w kolejnych edycjach po 1764 r.), Of the Dignity of Human Nature, Of Liberty and Despotism.

Drugi zbiór esejów: Essays Moral and Political, vol. II, Edinburgh 174; tom ten zawiera: Of Essay Writing (pominięte w wydaniu z 1748 r.), Of Eloquence, Of Moral Prejudices (pominięte w wydaniu z 1748 r.), Of the Middle Station of Life (pominięte w wydaniu z 1748 r.), Of the Rise and Progress of Arts and Sciences, The Epicurean, The Stoic, The Platonist, The Sceptic, Of Polygamy and Divorces, Of Simplicity and Refinement, A Character of Sir Robert Walpole (w wydaniu z $1748 \mathrm{r}$. zmniejszone do przypisu)).

Essays Moral and Political, London and Edinburgh 1748 (wydanie trzecie); dodano eseje: Of the Original Contract, Of Passive Obedience, Of National Characters.

${ }^{14}$ Informacje na podstawie: J. B. Stewart, The Moral and Political Philosophy of David Hume, Columbia University Press, New York-London 1963, s. 405 i nast. 
Political Discourses, Edinburgh 1751; tom zawiera: Of Commerce, Of Luxury, Of Money, Of Interest, Of the Balance of Trade, Of the Balance of Power, Of Taxes, Of Public Credit, Of Some Remarkable Customs, Of the Populousness of Antient Nations, Of the Protestant Succesion, Idea of a Perfect Commonwealth.

Four Dissertations, London 1757; dodano eseje: Of Tragedy, Of the Standard of Taste.

Essays and Treaties on Several Subjects, London 1758; dodano eseje: Of the Jealousy of Trade, Of the Coalition of Parties.

Essays and Treaties on Several Subjects, London and Edinburgh 1777; wydanie ukazało się już po śmierci Hume’a; dodano esej Of the Origin of Government.

Two Essays, London 1777; zawiera eseje Of Suicide, Of the Immortality of the Soul; w tym wydaniu eseje nie zostały zatytułowane; wraz z tytułami ukazały się po raz pierwszy w 1789 roku w Edynburgu jako Two essays. I. On suicide. II. On the mortality of the soul. By David Hume, Esq. Now first printed - podano wówczas zarówno nazwisko zarówno autora, jak i wydawcy C. Huntera.

\section{Polskie przekłady esejów Hume’a}

W Polsce eseje Hume'a ukazały się przede wszystkim w dwóch tomach: w przekładzie Teresy Tatarkiewiczowej (Eseje z dziedziny moralności i literatury, PWN, Warszawa 1955 - dalej jako E-PWN) oraz w przekładzie Łukasza Pawłowskiego (Eseje z dziedziny moralności, polityki i literatury, Wydawnictwo UW, Warszawa 2013 - dalej jako E-WUW). Wybory przekładów opublikowano również w trzech numerach czasopism: jako „Wybór esejów” w przekładzie Michała Filipczuka w „Principiach” (tom XXXII-XXXIII, 2002 - dalej jako E-PRN) oraz w tłumaczeniu różnych autorów w „Nowej Krytyce" (nr 20-21, 2007 - dalej jako E-NK), a także w przekładzie Natalii Karczewskiej w „Przeglądzie Filozoficznym. Nowej Serii” (nr 4, 2011 - dalej jako E-PF), pojedyncze przekłady esejów ukazywały się w kolejnych numerach "Studiów z Historii Filozofii”, a także w „Przeglądzie Filozoficznym”, „Odrze”, były także dołączane do polskich wydań Badań dotyczacych rozumu ludzkiego. Ponieważ w niektórych przypadkach eseje były przekładane 
kilkakrotnie, niekiedy pod nieco zmienionymi tytułami, poniżej zestawiono polskie tłumaczenia w kolejności ukazywania się esejów w języku angielskim.

Of the Delicacy of Taste and Passion

O wrażliwości smaku i uczuć, przeł. T. Tatarkiewiczowa, E-PWN.

O wrażliwości smaku i uczuć, przeł. Ł. Pawłowski, E-WUW.

Of the Liberty of the Press

O wolności słowa, przeł. T. Tatarkiewiczowa, E-PWN.

O wolności słowa, przeł. Ł. Pawłowski, E-WUW.

That Politics May Be Reduced to a Science

Czy polityka może być nauka, przeł. T. Tatarkiewiczowa, E-PWN.

Czy polityka może być nauką?, przeł. Ł. Pawłowski, E-WUW.

Of the First Principles of Government

O pierwszych zasadach rzadu, przeł. M. Filipczuk, E-PRN.

Of the Origin of Government

O początkach rządu, przeł. M. Filipczuk, E-PRN.

O pochodzeniu rzadu, przeł. Ł. Pawłowski, E-WUW.

Of the Independency of Parliament

O niezależności parlamentu, przeł. M. Filipczuk, E-PRN.

O niezależności parlamentu, przeł. Ł. Pawłowski, E-WUW.

Whether the British Government Inclines More to Absolute Monarchy, or to a Republic

O tym, czy ustrój brytyjski skłania się raczej ku monarchii, czy ku republice, przeł. M. Filipczuk, E-PRN.

Of Parties in General

O partiach w ogólności, przeł. M. Filipczuk, E-PRN.

O partiach w ogólności, przeł. Ł. Pawłowski, E-WUW.

Of the Parties of Great Britain

O partiach w Wielkiej Brytanii, przeł. A. Grzeliński, J. Trzepizur, „Studia z Historii Filozofii" 2016, nr 3. 
Of Superstition and Enthusiasm

O zabobonie i egzaltacji, przeł. T. Tatarkiewiczowa, E-PWN.

O zabobonie i fanatyzmie, przeł. Ł. Pawłowski, E-WUW.

Of the Dignity or Meanness of Human Nature

O dostojności i mierności natury ludzkiej, przeł. T. Tatarkiewiczowa, E-PWN.

O godności i podłości natury ludzkiej, przeł. Ł. Pawłowski, E-WUW.

Of Civil Liberty

O wolności obywatelskiej, przeł. Ł. Pawłowski, E-WUW.

Of Eloquence

O krasomówstwie, przeł. T. Tatarkiewiczowa, E-PWN.

Of the Rise and Progress of the Arts and Sciences

Powstanie i postęp sztuk i nauk, przeł. T. Tatarkiewiczowa, E-PWN.

O narodzinach i postępie sztuk i nauk, przeł. Ł. Pawłowski, E-WUW.

The Epicurean

Epikurejczyk, przeł. T. Tatarkiewiczowa, E-PWN.

The Stoic

Stoik, przeł. T. Tatarkiewiczowa, E-PWN.

Stoik, przeł. Ł. Pawłowski, E-WUW.

The Platonist

Platończyk, przeł. T. Tatarkiewiczowa, E-PWN.

Platonik, przeł. Ł. Pawłowski, E-WUW.

The Sceptic

Sceptyk, przeł. T. Tatarkiewiczowa, E-PWN.

Sceptyk, przeł. Ł. Pawłowski, E-WUW.

Of Polygamy and Divorces

Wielożeństwo i rozwód, przeł. T. Tatarkiewiczowa, E-PWN. 
Of Simplicity and Refinement in Writing

O prostym i wyszukanym stylu, przeł. T. Tatarkiewiczowa, E-PWN.

Of National Characters

O charakterze narodowym, przeł. T. Tatarkiewiczowa, E-PWN.

O charakterach narodowych, przeł. Ł. Pawłowski, E-WUW.

Of Tragedy

O tragedii, przeł. T. Tatarkiewiczowa, E-PWN oraz w: Arystoteles, D. Hume, M. Scheler, O tragedii i tragiczności, przeł. W. Tatarkiewicz, T. Tatarkiewicz, R. Ingarden, Wyd. Literackie, Kraków 1976.

Of the Standard of Taste

Sprawdzian smaku, przeł. T. Tatarkiewiczowa, E-PWN.

O kryterium dobrego smaku, przeł. Ł. Pawłowski, E-WUW.

Of Commerce

O handlu, przeł. S. Zabieglik, E-NK.

Of Refinement in the Arts

O doskonaleniu sztuki, przeł. T. Tatarkiewiczowa, E-PWN.

O doskonaleniu sztuk, przeł. Ł. Pawłowski, E-WUW.

Of Money

O pieniądzu, przeł. A. Grzeliński, „Studia z Historii Filozofii” 2014, nr 1.

Of Interest

O procencie, przeł. A. Grzeliński, K. Wawrzonkowski, „Studia z Historii Filozofii” 2014, nr 4.

Of the Balance of Trade

O równowadze w handlu, przeł. D. Kosiewicz-Wawrzonkowska, „Studia z Historii Filozofii” 2015, nr 1.

Of the Jealousy of Trade

O zawiści w handlu, przeł. K. Wawrzonkowski, „Studia z Historii Filozofii" 2015, nr 4. 
Of the Balance of Power

O równowadze sił, przeł. Ł. Pawłowski, E-WUW.

Of Taxes

O podatkach, przeł. S. Zabieglik, „Pieniądze i Więź” 2000, nr 2.

Of Public Credit

O kredycie publicznym, przeł. A. Grzeliński, A. Markwart, „Studia z Historii Filozofii” 2016, nr. 1.

Of Some Remarkable Customs

O pewnych niezwykłych zwyczajach, przeł. Ł. Pawłowski, E-WUW.

O kilku godnych uwagi zwyczajach, przeł. D. Kosiewicz-Wawrzonkowska, „Studia z Historii Filozofii” 2016, nr 2.

Of the Populousness of Ancient Nations

O ludności czasów dawnych y teraźniejszych przez P. Hume, przeł. (z j. franc.) A. Kamiński, Wrocław 1785.

Of the Original Contract

O umowie założycielskiej, przeł. M. Filipczuk, E-PRN.

O umowie społecznej, przeł. Ł. Pawłowski, E-WUW.

Of Passive Obedience

O biernym posłuszeństwie, przeł. M. Filipczuk, E-PRN.

O biernym posłuszeństwie, przeł. Ł. Pawłowski, E-WUW.

Of the Coalition of Parties

O przymierzach między partiami, przeł. Ł. Pawłowski, E-WUW.

O koalicji partii, przeł. A. Grzeliński, K. Wawrzonkowski, „Studia z Historii Filozofii" 2014, nr 2.

Of the Protestant Succession

O sukcesji protestanckiej, przeł. J. Trzepizur, „Studia z Historii Filozofii” 2016, nr 3. 
Idea of a Perfect Commonwealth

Idea doskonałej wspólnoty, przeł. D. Żuromski, „Studia z Historii Filozofii” 2016, nr 4.

Of Essay-Writing

O pisaniu esejów, przeł. N. Karczewska, E-PF.

O pisaniu esejów, przeł. T. Sieczkowski, w: D. Hume, Badania dotyczące rozumu ludzkiego, przeł. D. Misztal, T. Sieczkowski, Kraków 2004.

Of Moral Prejudices

O przesądach moralnych, przeł. M. Kotowski, „Odra” 2011, nr 5.

O uprzedzeniach moralnych, przeł. N. Karczewska, E-PF.

O uprzedzeniach moralnych, przeł. M. Szymańska-Lewoszewska, „Studia z Historii Filozofii” 2015, nr 2.

Of the Middle Station of Life

O średniej pozycji w życiu, przeł. N. Karczewska, E-PF.

O stanie średnim, przeł. B. Żukowski, E-NK.

Of Impudence and Modesty

O zuchwałości i skromności, przeł. M. Kotowski, „Odra” 2011, nr 5.

O zuchwalstwie i skromności, przeł. N. Karczewska, E-PF.

Of Love and Marriage

O miłości i małżeństwie, przeł. J. Grzyl, E-NK.

O miłości i małżeństwie, przeł. N. Karczewska, E-PF.

Of the Study of History

O studiowaniu historii, przeł. P. Michalski, E-NK.

Of Avarice

O skapstwie, przeł. K. Kędziora, E-NK.

A Character of Sir Robert Walpole

Opis charakteru sir Roberta Walpole'a, przeł. T. Sieczkowski, E-NK. 


\title{
Of Suicide
}

Esej o samobójstwie, przeł. A. Hochweldowa, w: D. Hume, Dialogi o religii naturalnej, Warszawa 1962.

O samobójstwie, przeł. T. Sieczkowski, w: D. Hume, Badania dotyczące rozumu ludzkiego, przeł. D. Misztal, T. Sieczkowski, Kraków 2004.

Of the Immortality of the Soul

O nieśmiertelności duszy, przeł. T. Tatarkiewiczowa, E-PWN.

O nieśmiertelności duszy, przeł. T. Sieczkowski, w: D. Hume, Badania dotyczace rozumu ludzkiego, przeł. D. Misztal, T. Sieczkowski, Kraków 2004.

\begin{abstract}
Hume's Essays and their Polish Translations. A Bibliographical Note

Most of Polish translations of David Hume's essays have been collected in two wellknown volumes edited by T. Tatarkiewiczowa and $Ł$. Pawłowski, but some of them were also published in various scientific journals. Moreover, some are also available in two, or even three Polish versions, whereas some were not available in Polish until they were translated and published in several issues of this journal. The dissipation of translations and functioning of various versions of their titles cause problems for Hume scholarship in Poland. In answer to this problem the article collates all existing Polish translations of Hume's essays.
\end{abstract}

Key words: David Hume, essays, editions, Polish translations 